\title{
Research observation: Hydrolyzable and condensed tannins in plants of northwest Spain forests
}

\author{
*M.P. GONZÁLEZ-HERNÁNDEZ ${ }^{1}$, J. KARCHESY² AND E.E. STARKEY ${ }^{3}$
}

Authors are Professor, Department of Crop Production, Santiago de Compostela University, 27002 Lugo, Spain; Associate Professor, College of Forestry, Oregon State University, 3200 SW Jefferson Way, Corvallis, Ore. 97311; and Research Biologist, USGS-Forest and Rangeland Ecosystem Science Center, 3200 SW Jefferson Way, Corvallis, Ore. 97311.

\begin{abstract}
Tannins are secondary metabolites that may influence feeding by mammals on plants. We analyzed hydrolyzable and condensed tannins in 30 plant species consumed by livestock and deer, as a preliminary attempt to study their possible implications on browsing and grazing in forest ecosystems. Heathers (Ericaceae) and plants of the Rose (Rosaceae) family had tannins, while forbs, grasses and shrubs other than the heathers did not show astringency properties. We found the highest tannin content of all the species in Rubus sp., with the highest value around $180 \mathrm{mg}$ TAE/g dry weight in spring. Potentilla erecta, Alnus glutinosa and Quercus robur were next with 57 to $44 \mathrm{mg}$ TAE/g dw. Total tannins in heathers ranged from 22 to $36 \mathrm{mg} \mathrm{TAE} / \mathrm{g} \mathrm{dw}$. Levels of condensed tannins were higher than hydrolyzable for most of the species. Only Betula alba, Calluna vulgaris, Pteridium aquilinum and Vaccinium myrtillus had $100 \%$ hydrolyzable tannins. Tannin content of the species changed seasonally with highest values during the growing season, corresponding to late winter or early spring, depending on the species.
\end{abstract}

Key Words: astringency, nutritional quality, Galicia

Tannins are polyphenolic compounds that have become widely recognized as important factors influencing feeding by mammals on woody plants (Robbins et al. 1987, Happe et al. 1990, Bryant et al. 1992, Hagerman et al. 1992, McArthur et al. 1993, Haslam 1998). They are secondary metabolites that may inhibit digestion of protein and fiber or their characteristically astringent taste may cause flavor aversion and adversely affect feed intake (Provenza et al. 1990, Bryant et al. 1992, Hagerman et al. 1992).

Most studies of tannins have focussed on nontoxic effects on availability of protein. Condensed and hydrolizable tannins combine with protein to form tannin-protein complexes during mastication and digestion of forage (Hagerman et al. 1992). Formation of these stable complexes may reduce the amount of digestible protein available for herbivores and digestibility of forage may also be reduced if rumen microflora are negatively influenced by tannins.

The research was developed at the Oregon State University during the stay of the first author funded by the Secretary of Research and Development, Xunta de Galicia, Spain. We thank $M^{a}$ José Rozados Lorenzo and Margarita Alonso Santos for their helpful assistance in the sampling and liophylization of plant material. Dr. $\mathrm{M}$. Ralphs and 3 anonymous reviewers helped to improve the manuscript with valuable suggestions.

Manuscript accepted 14 Oct. 02.

\section{Resumen}

Los taninos son metabolitos secundarios que pueden influir en la utilización de las plantas como alimento por los mamíferos. Analizamos los taninos condensados e hidrolizables de 30 especies de plantas consumidas por el ganado doméstico y el corzo, como un intento preliminar para estudiar sus posibles implicaciones en el ramoneo y pastoreo en ecosistemas forestales. Las rosáceas (Rosaceae) y los brezos (Ericaceae) tuvieron taninos, mientras que otros arbustos y las herbáceas no mostraron propiedades de astringencia. En Rubus sp., encontramos el más alto contenido de taninos de todas las especies, con el mayor valor en primavera (180 mg TAE/g de peso seco). Potentilla erecta, Alnus glutinosa y Quercus robur fueron los siguientes con más alto contenido de taninos, entre 57 y $44 \mathrm{mg}$ TAE/g de peso seco. Los taninos totales en los brezos variaron de 26 a $36 \mathrm{mg}$ TAE/g de peso seco. En la mayoría de las especies los niveles de taninos condensados fueron mayores que los de taninos hidrolizables. Sólo Betula alba, Calluna vulgaris, Pteridium aquilinum y Vaccinium myrtillus tuvieron el $100 \%$ de taninos hidrolizables. El contenido de taninos en las plantas cambió estacionalmente, presentándose los mayores valores durante la estación de crecimiento, correspondiendo a final del invierno o principio de la primavera, dependiendo de las especies.

In Galicia, the biomass of combustible plant material becomes very abundant. The use of vegetation by livestock and deer can be a useful tool to reduce forest fires, and silvopastoral systems have been reported as an alternative of socioeconomic and environment interest within the multiple use of forest (Silva-Pando and González-Hernández 1992, Silva-Pando et al. 1998, Rigueiro et al. 1999). The nutritional attributes of plants commonly found in Galician forests have been reported in previous research (González-Hernández and Silva-Pando 1999), but there is a lack of information about their content of antifeedant compounds like tannins.

The aim of this study was to analyze both the hydrolyzable and condensed tannin content of plants found in deer and livestock diets as a preliminary attempt to discuss their possible implications on browsing and grazing within forest ecosystems. We measured their astringency (capacity of tannins to form insoluble tannin-protein complexes) to determine their potential for reducing digestibility. 


\section{Study Area}

The study area is located in Galicia (northwest Spain, $43^{\circ} \mathrm{N}, 8^{\circ} \mathrm{W}$ ) and included forest vegetation communities of this region such as deciduous oakwoods, conifer stands, and shrublands (broom, gorse, and heathlands). Oak forests constitute climax stage vegetation but are fragmented in most of the cases because of agriculture and other human uses in the past. Conifer, together with eucalyptus stands, come from reforestation, and their understory consists of seral succesional stages of plant communities between shrublands (broom-gorse-heatherlands) and the climax oak forests.

Climate is Atlantic with mild, wet winters at the coast, and colder inland. Continentality increases from the coast to inland areas where summers are dryer. Maximum temperatures increase and minimum decrease from northwest to southeast with annual mean temperatures varying from 7.3 to $14.2^{\circ} \mathrm{C}$, and annual precipitation from 1,419 to $2,037 \mathrm{~mm}$. Elevation ranged from 60 to $1,280 \mathrm{~m}$. Soils in Galicia are mainly acid and the rock is granite, slate, or schists.

\section{Material and Methods}

Plants known as components of livestock and deer diets were considered for analysis of tannin content (Table 1). For each species, plant material with similar age and within homogenous site condition was clipped and combined into a single sample for analysis. Hand harvested plant parts were representative of plant parts that deer or livestock would select, corresponding to apical portions of shrubs no longer than $15 \mathrm{~cm}$ and less than $1 \mathrm{~cm}$ in twig diameter, and leaves from trees taken within browsing heights. Plants were harvested during their growing season, which for most of them occurred in spring. Perennials were harvested seasonally within the same year to study their tannin variation through the seasons. Plants of species analized seasonally were not sampled more than once.

Fresh plant material was transported immediately to the laboratory where it was lyophilized and stored frozen until analysis. Before analysis the samples were ground through a Wiley mill with $1 \mathrm{~mm}$ mesh screen.

Tannins were extracted with $70 \%$ acetone at room temperature. One gram of ground plant material was stirred with 10

Table 1. Species analized and type of vegetation where they predominantly occur.

\begin{tabular}{|c|c|c|}
\hline Life form & Species & Vegetation type \\
\hline Trees & $\begin{array}{l}\text { Alnus glutinosa }(\mathrm{L} .) \text { Gaertner } \\
\text { Betula alba } \mathrm{L} . \\
\text { Fagus sylvatica } \mathrm{L} . \\
\text { Ilex aquifolium } \mathrm{L} . \\
\text { Quercus robur } \mathrm{L} . \\
\text { Salix atrocinerea Brot. }\end{array}$ & $\begin{array}{l}\text { (riparian areas) } \\
\text { (riparian areas) } \\
\text { (oakwood ) } \\
\text { (oakwood ) } \\
\text { (oakwood) } \\
\text { (riparian areas) }\end{array}$ \\
\hline Shrubs & $\begin{array}{l}\text { Calluna vulgaris (L.) Hull } \\
\text { Cytisus multiflorus (L'Hér.) Sweet } \\
\text { Cytisus striatus (Hill) Rothm. } \\
\text { Daboecia cantabrica (Hudson) C. Koch } \\
\text { Erica arborea L. } \\
\text { Erica australis } \mathrm{L} . \\
\text { Erica vagans } \mathrm{L} . \\
\text { Erica umbellata } \mathrm{L} . \\
\text { Frangula alnus } \text { Miller } \\
\text { Genista florida } \text { L. } \\
\text { Halimium lasianthum (Lam.) Spach } \\
\text { Hedera helix L. } \\
\text { Lonicera periclymenum L. } \\
\text { Pterospartum tridentatum (L.) Willk. } \\
\text { Rubus } \text { sp. } \\
\text { Ulex europaeus } \text { L. } \\
\text { Vaccinium myrtillus } \text { L. }\end{array}$ & $\begin{array}{l}\text { (conifer, eucalyptus, shrubland) } \\
\text { (shrubland, oakwood) } \\
\text { (shrubland, oakwood) } \\
\text { (conifer, heatherland, eucalyptus) } \\
\text { (oakwood, shrubland) } \\
\text { (shrubland ) } \\
\text { (shrubland ) } \\
\text { (conifer, eucalyptus, shrubland ) } \\
\text { (oakwood ) } \\
\text { (oakwood, shrubland) } \\
\text { (conifer, shrubland) } \\
\text { (oakwood ) } \\
\text { (oakwood ) } \\
\text { (conifer, eucalyptus, shrubland) } \\
\text { (oakwood , conifer, shrubland) } \\
\text { (conifer, shrubland) } \\
\text { (oakwood) }\end{array}$ \\
\hline Ferns & Pteridium aquilinum (L.) Kuhn & (conifer, oakwood) \\
\hline Forbs & $\begin{array}{l}\text { Asphodelus albus Miller } \\
\text { Potentilla erecta (L.) Raüschel }\end{array}$ & $\begin{array}{l}\text { (conifer, eucalyptus) } \\
\text { (conifer, eucalyptus, shrublands) }\end{array}$ \\
\hline Grasses & $\begin{array}{l}\text { Agrostis curtisii Kerguélen } \\
\text { Pseudarrhenatherum longifolium (Thore) Rouy }\end{array}$ & $\begin{array}{l}\text { (conifer, oakwood) } \\
\text { (conifer, oakwood ) }\end{array}$ \\
\hline
\end{tabular}

$\mathrm{ml}$ of acetone for 15 minutes. The mixture was then centrifuged for 5 minutes in a clinical centrifuge $(5000 \mathrm{~g})$. The supernatant was saved and the sample extracted for 15 minutes again with fresh solvent. The process was repeated a total of 4 times. Acetone was evaporated from the supernatant with a rotary evaporator in a $30^{\circ} \mathrm{C}$ water bath. The remaining aqueous solution was rinsed twice with an equal quantity of ethyl ether to remove low molecular weight tannins (Broadhurst and Jones 1978). Remaining ethyl ether was evaporated with a rotary evaporator and distilled water was added to result in a total volume of $25 \mathrm{ml}$. Extracts were placed in sealed polypropylene test tubes and stored in a freezer at $-10^{\circ} \mathrm{C}$.

An index of protein precipitating capacity is commonly determined by the capacity of known amounts of plant extracts or tannins to precipitate bovine serum albumin (BSA). In this paper, astringency, or the capacity of tannins to precipitate proteins, was determined using the radial diffusion technique of Hagerman (1987), based on bovine serum albumin precipitation on agar plates. Selective determination of hydrolyzable and condensed tan- nins was made using the modified radial diffusion technique (Hagerman 1995) founded on the susceptibility of hydrolyzable tannins to degradation by hydroxylamine. With this method, samples containing only hydrolyzable tannins do not precipitate when radial diffusion is performed after addition of hydroxylamine since the tannin is decomposed. The estimation of condensed and hydrolyzable tannins was based on the difference between the area of the ring obtained before and after the reaction with hydroxylamine. Condensed tannins do not react to hydroxylamine and therefore the radial diffusion measurement is the same before and after hydroxylaminolysis. We used tannic acid as standard. All samples were analyzed in duplicate.

\section{Results and Discussion}

Tannins were present in many of the plants analyzed (Table 2), such as heathers (Ericaceae) and plants of the Rosaceae family. We found the highest tannin content in Rubus sp., Potentilla erecta, Alnus glutinosa and Quercus robur. Condensed 
tannins were predominant in most of these species. Concentrations of 75-100 $\mathrm{g}$ of condensed tannins/kg dry matter have depressed voluntary feed intake and rumen carbohydrate digestion as well as rates of body and wool growth in grazing sheep, while values of 30-40 g of condensed tannins/kg provided nutritional benefits (Barry and McNabb 1999). Based on these values, Rubus sp. could limit feed intake for some herbivores. In Galicia, only young sprouts of Rubus sp. are ocasionally browsed by horses and goats, and they have not been found to be part of cattle diets (Rigueiro et al. 1998). However, this species is very palatable for roe deer, mainly during fall and winter (Jackson 1980, Hosey 1981, Maizeret and Tran Manh Sung 1984, Costa Pérez 1992, Putnam 1996); these seasons correspond to the lowest levels of tannins we found in our study.
As opposed to the highest proportion of condensed tannins we found in Rubus sp., Starkey et al. (1999) have shown Rubus spectabilis in the Pacific Northwest have higher concentrations of hydrolyzable tannins than condensed. In our study, some plants such as Betula alba, Calluna vulgaris, Vaccinium myrtillus and Pteridium aquilinum, contained $100 \%$ hydrolyzable tannins.

There are apparently conflicting claims of beneficial and toxic effects caused by hydrolyzable tannins in various animal species (Jean-Blain 1998, Aerts et al. 1999, Clifford and Scalbert 2000) and the biological significance of different types of tannins, including their role in nutritional ecology. Some studies have reported the preference of deer for medium level hydrolyzable tannin pellets $(3.8 \%)$ instead of control pellets without tannins, and have showed that daily consumption of pellets containing high level of tannins
(9.1\%) was lower than consumption of the control (Verheyden-Tixier and Duncan 2000). Studies of roe deer diets have found Calluna vulgaris and Vaccinium myrtillus appear in higher rates compared to other species of Erica in the same study area (Putnam 1996). We found most of plants in the Ericaceae family have predominantly condensed tannins except Calluna vulgaris and Vaccinium myrtillus with $100 \%$ hydrolyzable (Table 2).

Tannin content of the species changed seasonally. For those plants with tannins, the seasonal variation is showed in Figure 1. We obtained the highest values during the growing season, corresponding to late winter or early spring, depending on the species. There is a tendency of hydrolyzable tannins to be highest in the winter. Halimium lasianthum had $100 \%$ condensed tannins in the spring, but hydrolyzable tannins increased to $14 \%$ in winter

Table 2. Total, and percentages of hydrolyzable and condensed tannins in plants known as components of livestock and deer diets. Values correspond to spring. Total tannins are expressed in mg tannic acid eq/g dry weight. Percentages of crude protein (CP) are shown for some of the species (González-Hernández 1994). Species with absence of tannins are presented at the bottom of the table (-).

\begin{tabular}{|c|c|c|c|c|c|c|c|}
\hline Life form & Species & $\begin{array}{c}\text { Common } \\
\text { name }\end{array}$ & Family & $\begin{array}{c}\text { Total } \\
\text { tannins }\end{array}$ & Hyd & Cond & $\mathrm{CP}$ \\
\hline \multirow[t]{6}{*}{$\overline{\text { Trees }}$} & & & & (mg TAE/g) & $(\%)$ & $(\%)$ & $(\%)$ \\
\hline & Alnus glutinosa & alder & Betulaceae & 57.11 & 30.1 & 69.9 & \\
\hline & Betula alba & galician birch & Betulaceae & 12.85 & 100 & 0 & \\
\hline & Fagus sylvatica & beech & Fagaceae & 24.36 & 27.0 & 73.0 & 7.8 \\
\hline & Quercus robur & oak & Fagaceae & 43.87 & 10.2 & 89.8 & 9.0 \\
\hline & Salix atrocinerea & black willow & Salicaceae & 40.43 & 28.1 & 71.9 & \\
\hline \multicolumn{8}{|l|}{ Shrubs } \\
\hline & Halimium lasianthum & cistus & Cistaceae & 32.70 & 0 & 100 & 7.3 \\
\hline & Erica vagans & heather & Ericaceae & 22.36 & 24.9 & 75.1 & \\
\hline & Calluna vulgaris & heather & Ericaceae & 25.37 & 100 & 0 & 6.1 \\
\hline & Erica australis & heather & Ericaceae & 29.51 & 5.2 & 94.8 & 6.6 \\
\hline & Erica umbellata & heather & Ericaceae & 31.63 & 24.9 & 75.1 & 6.7 \\
\hline & Vaccinium myrtillus & bilberry & Ericaceae & 14.68 & 100 & 0 & 7.4 \\
\hline & Erica arborea & tree heather & Ericaceae & 35.96 & 32.2 & 67.8 & 7.8 \\
\hline & Daboecia cantabrica & heather & Ericaceae & 33.78 & 10.3 & 89.7 & 8.5 \\
\hline & Rubus sp. & bramble & Rosaceae & 181.60 & 25.5 & 74.5 & 10.4 \\
\hline \multicolumn{8}{|l|}{ Forbs } \\
\hline & Potentilla erecta & tormentila & Rosaceae & 46.20 & 2.6 & 97.4 & 9.8 \\
\hline \multicolumn{8}{|l|}{ Ferns } \\
\hline & Pteridium aquilinum & bracken fern & Hypolepidaceae & 4.16 & 100 & 0 & 13.0 \\
\hline \multicolumn{8}{|l|}{ Trees } \\
\hline & Ilex aquifolium & holly & Aquifoliaceae & - & & & 8.3 \\
\hline \multicolumn{8}{|l|}{ Shrubs } \\
\hline & Hedera helix & ivy & Araliaceae & - & & & 9.3 \\
\hline & Lonicera periclymenum & honeysuckle & Caprifoliaceae & - & & & 9.7 \\
\hline & Pterospartum tridentatum & carqueixa & Fabaceae & - & & & 7.3 \\
\hline & Ulex gallii & gorse & Fabaceae & - & & & 9.3 \\
\hline & Cytisus multiflorus & broom & Fabaceae & - & & & 12.3 \\
\hline & Ulex europaeus & gorse & Fabaceae & - & & & 8.7 \\
\hline & Cytisus striatus & broom & Fabaceae & - & & & 15.3 \\
\hline & Genista florida & broom & Fabaceae & - & & & 18.0 \\
\hline & Frangula alnus & black dogwood & Rhamnaceae & - & & & 11.7 \\
\hline \multicolumn{8}{|l|}{ Forbs } \\
\hline & Asphodelus albus & white asphodel & Liliaceae & - & & & 17.4 \\
\hline \multicolumn{8}{|l|}{ Grasses } \\
\hline & Agrostis curtisii & bent-grass & Poaceae & - & & & 9.3 \\
\hline & Pseudarrhenatherum longifolium & grass & Poaceae & - & & & 8.6 \\
\hline & Dactylis glomerata & orchardgrass & Poaceae & - & & & 17.4 \\
\hline
\end{tabular}




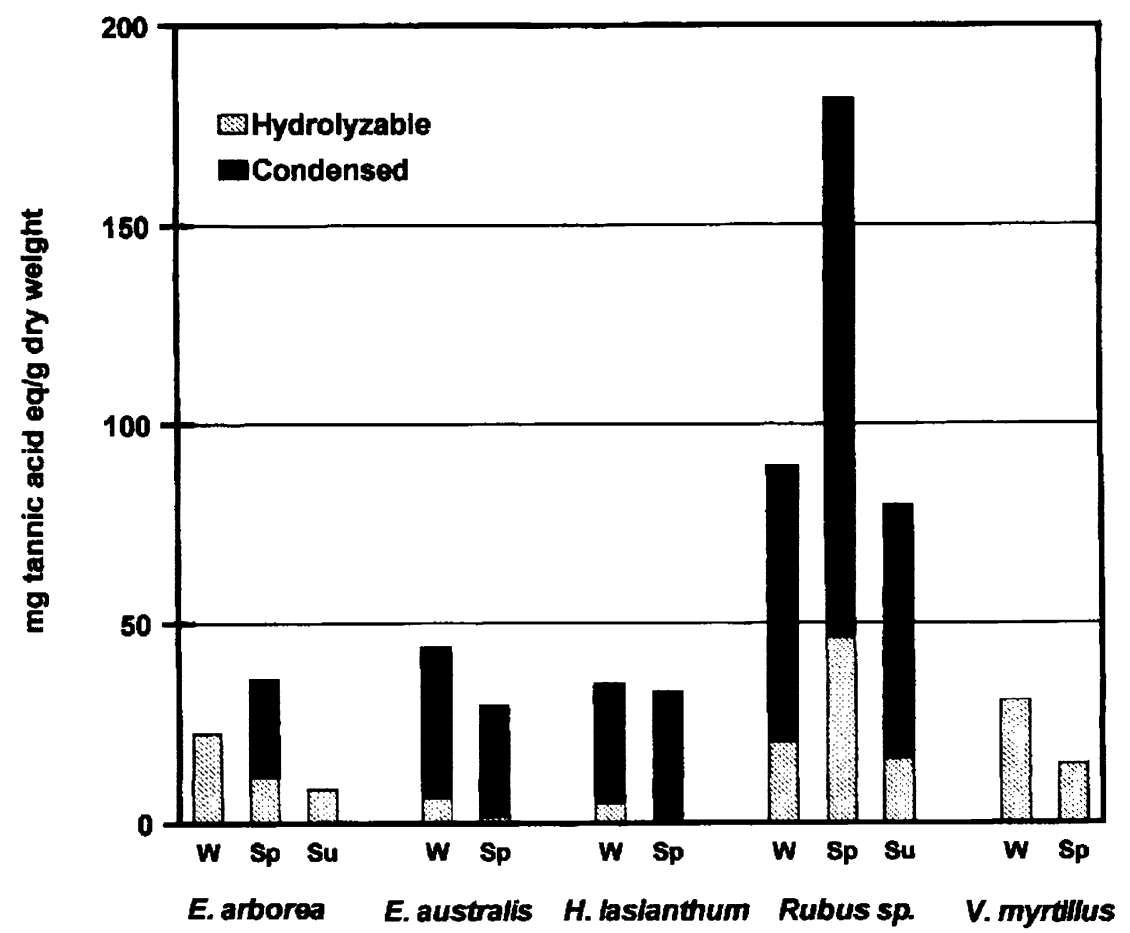

Fig. 1. Winter, spring and summer concentrations of hydrolyzable and condensed tannins (mg tannic acid eq/g dry weight).

(Fig. 1). Erica arborea tannin concentrations increased in spring, and the ratio of tannins changed from $67.8 \%$ condensed in spring to $100 \%$ hydrolyzable during the summer and winter.

We reported in previous studies the low digestibility of plants of Galician woodlands as an important limiting factor in livestock production (González-Hernández and Silva-Pando 1999). Digestible protein can be a significant limiting factor for some deer and elk populations because the tannin content in the plants limit its availability (Starkey et al. 1999). Available protein, rather than total protein content, has been reported as the physiologically important parameter relative to animal requirements and metabolic capabilities (Robbins et al. 1987)

Other plants analyzed in our study such as leguminose shrubs and grasses did not contain tannins (Table 1). Neither did other plants such as holly (Ilex aquifolium), ivy (Hedera helix), honeysuckle (Lonicera periclymenum) and black dogwood (Frangula alnus); all of them are considered of high preference in herbivore diets and with good nutritional attributes (Costa 1992, Fandos et al. 1987, Clutton-Brock and Albon 1989, Putnam 1996, GonzálezHernández and Silva-Pando 1999).

Hervibores may ameliorate the effects of certain tannins in natural forages on protein digestibility through physiological and behavioural adaptations, and some

\section{Literature cited}

Aerts, R. J., T.N. Barry, and W.C. McNabb. 1999. Polyphenols and agriculture: beneficial effects of proanthocyanidins in forages. Agr. Ecosyst. Environ. 75, (1-2):1-12.

Austin, P.J., L.A. Suchar, C.T. Robbins, and A.E. Hagerman. 1989. Tannin-binding proteins in saliva of sheep and cattle. J. Chem. Ecol. 15: 1335-47.

Barry, T. N. and W.C. McNabb. 1999. The implications of condensed tannins on the nutritive value of temperate forages fed to ruminants. Br. J. Nutr. 81(4):263-272.

Broadhurst, R.B. and W.T. Jones. 1978. Analysis of condensed tannins using acidified vanillin. J. Sci. Fd. Agr. 29:788-794.

Bryant, J.P, P.B. Reichardt, and T.P. Clausen. 1992. Chemically mediated interactions between woody plants and browsing mammals. J. Range. Manage. 45 (1):18-24.

Clifford, M.N. and A. Scalbert. 2000 Ellagitannins - nature, occurrence and dietary burden. J. Sci. Food Agr. 80(7):1118-1125.

Clutton-Brock, T.H. and S.D. Albon. 1989. Red deer in the Highlands. Blackwell Scientific Publications, Oxford.

Costa Pérez, L. 1992. Ecología del corzo en las montañas cantábricas. Modelo de gestión. $\mathrm{PhD}$ thesis. Universidad de León. Spain.

Fandos, P., T. Martínez, and F. Palacios. 1987. Estudio sobre la alimentación del corzo (Capreolus capreolus L. 1758) en España. Ecología 1:161-186.

González Hernández, M.P. and F.J. SilvaPando. 1999. Nutritional attributes of understory plants known as components of deer diets. J. Range Manage 52 (2):132-138.

Hagerman, A.E. 1987. Radial diffusion method for determining tannin in plant extracts. J. Chem. Ecol. 13:437-449.

Hagerman. A.E. 1995. Tannin Analysis. Miami University, $66 \mathrm{pp}$.

Hagerman, A.E., C.T. Robbins, Y. Weerasuriya, T.C. Wilson, and C. McArthur. 1992. Tannin chemistry in relation to digestion. J. Range. Manage. 45 (1): $57-62$.

Happe, P.J., K.J. Jenkins, E.E. Starkey, and S.H. Sharrow. 1990. Nutritional quality and tannin astringency of browse in clear-cuts and old-growth forests. J. Wildl. Manage., 54 (4):557-566

In Galician forests, many forage species contain significant levels of astringent tannins with the potential to greatly reduce the availability of protein for livestock and deer. Digestible protein is likely to be a significant limiting factor in forest communities containing predominantely plants of the Ericaceae family, especially if grasses or forbs are not available. Understory of conifer and eucalyptus stands, as well as some shrublands, consist mainly of heathers, and could be more limited in the digestible protein available for deer and livestock than oakwoods and other shrublands containing predominantely gorse or broom.
Haslam, E. 1998. Practical polyphenolics. From structure to molecular recognition and physiological action. Cambridge University Press. $422 \mathrm{pp}$

Hosey, G. 1981. Annual foods of the Roe deer (Capreolus capreolus) in the south of England. J. Zool. 194 (2):276-278.

Jackson, J. 1980. The annual diet of Roe Deer (Capreouls capreolus) in the new forest, Hampsire, as determined by rumen content analysis. J. Zool. 192 (1):71-81.

Jean-Blain, C. 1998. Nutritional and toxicological aspects of tannins. Rev. Med. Vet. 149(10):911-920. 
Maizeret, C. and Tran Manh Sung, 1984. Etude du régime alimentaire et recherche du déterminisme fonctionnel de la sélectivité chez le chevreuil (Capreolus capreolus) des Landes de Gascogne. Gibier Faune Sauvage, 3:63-103.

McArthur, C., C.T. Robbins, A.E. Hagerman, and T.A. Hanley. 1993. Diet selection by a ruminant generalist browser in relation to plant chemistry. Can. J. Zool. 71: 2236-2243.

Provenza, F.D., E.A. Burrit, T.P. Clausen, J.P. Bryant, P.B. Reichardt, and R.A. Distel. 1990. Conditioned flavor aversion: A mechanism for goats to avoid condensed tannins in blackbush. Amer. Natur. 136,810-828.

Putman, R.J. 1996. Competition and resource partitioning in temperate ungulate assemblies. Chapman and Hall (London).

Rigueiro Rodríguez, A., M.R. MosqueraLosada, and M.L. López-Díaz. 1999. Sylvopastoral systems in prevention of forest fires in the forests of Galicia (NW of Spain). Agroforestry forum, 9, (3), 3-7.
Rigueiro, A., F.J. Silva-Pando, R. Rodríguez, P.A. Castillón, P. Álvarez, R. Mosquera, R. Romero, and M.P. GonzálezHernández. 1998. Manual de Sistemas Silvopastorales. Monografías del Proxecto Columela. Area forestal. Serie Manuales Técnicos. Escuela Politécnica de Lugo. Universidad de Santiago de Compostela.

Robbins, C.T., T.A. Hanley, A.E. Hagerman, O. Hjeljord, D.L. Baker, C.C. Achwartz, and W.W. Mautz. 1987. Role of tannins in defending plants against ruminants: reduction in protein availability. Ecol. 68(1):98-107.

Silva-Pando, F.J. and M.P. GonzálezHernández. 1992. Agroforestry helps prevent forest fires. Agroforestry today, 4 (4)7-9.

Silva-Pando, F. J., M.P. González Hernández, A. Rigueiro, M.J. Rozados Lorenzo, and A. Prunell. 1998. Livestock grazing under pinewood and eucalyptus forests: multiple use in Northwest Spain. Agroforestry Forum 9, (1):36-43.
Starkey, E.E., P. J. Happe, M. P. GonzalezHernandez, K. Lange, and J. Karchesy. 1999. Tannins as nutritional constraints for elk and deer of the coastal Pacific Northwest. In: G.G. Gross, R.W. Heming-way, and T. Yoshida Eds. Plant polyphenols 2: Chemistry, biology, pharmacology, ecology. pp. 897-908. Kluwer Academic/ Plenum Publishers, New York. USA.

Verheyden-Tixier, T.H. and P. Duncan. 2000. Selection for small amounts of hydrolysable tannins by a concentrate-selecting mammalian herbivore. J. Chem. Ecol. 26(2):351-358 